\author{
MICHAEL K. KOMANECKY
}

\title{
Jo Mora and the Missions of California
}

7 he missions of Alta California and their churches were depicted repeatedly by generations of artists who traveled to the American West. ${ }^{\mathrm{I}}$ The first were those who accompanied the now famous voyages of discovery of Jean François de Galaup de la Pérouse in I78 5-I 788 , Alessandro Malaspina in I79I-I 794, George Vancouver in I79I-I795, Otto von Kotzebue in I 8 I 5-I 8 I 8 , and Frederick William Beechey in I825-I 828. The monarchs and nations who sponsored these expeditions were driven largely by geopolitical concerns; France, Russia, and England sought to counter Spain's presence in the region and, at the same time, to take advantage of the lucrative fur trade, while Spain endeavored to solidify its hold on its northwestern-most corner of New Spain. From the artists who accompanied these voyages - Gaspard Duché de Vancy with Pérouse, ${ }^{2}$ José

I. This larger phenomenon will be explored in the author's forthcoming essay, "New Spanish Missions in the American Imagination", to be published in the exhibition catalogue for The Art of the Missions of Northern New Spain. The exhibition, organized by Clara Bargellini of the Instituto de Investigaciones Estéticas at the Universidad Nacional Autónoma de México and the author, will open in March 2008 at the Antiguo Colegio de San Ildefonso in Mexico City before traveling to museums in the United States through 2009.

2. La Pérouse and his crew were lost at sea in 1788 , although his journals were sent back to Paris from various ports of call during his voyage. They were published posthumously as Voyage de la Pérouse autour du monde publié conformément au décret du 22 Avril 1791 et rédigé par M.L.A. Milet Mureau, Paris, L'Imprimerie de la République, I797, 4 vols. Chapter XI includes a section on Details historiques sur les deux Californies et sur leurs missions, vol. I, pp. 247-283. Pérouse's original manuscript was only recently rediscovered and has been published as The Journal of Jean-François de Galaup de la Pérouse, 1785-1788, John Dunmore (trans. and ed.), 
Cardero with Malaspina, ${ }^{3}$ John Sykes with Vancouver, ${ }^{4}$ Louis Choris with von Kotzebue, ${ }^{5}$ and William Smyth with Beechey ${ }^{6}$ - came the first published images of the missions in northern New Spain. California's geopolitical importance, initially for Spain, then Mexico, and finally as part of the United States, generated significant artistic interest in its missions that continued virtually without cease well into the twentieth century.

Joseph Jacinto Mora (I 876-1947) was one of many who found these missions attractive subjects for his work. 7 Born on October 22, I 876 in Mon-

London, The Hakluyt Society, 1994, 2 vols. Duché de Vancy's appointment is noted in Voyage de la Pérouse autour du monde, vol. I, p. 5. The only reliable biography of the artist, albeit brief, is in Dunmore, pp. lxxxv-lxxxvi.

3. The primary source for the artists on the Malaspina expedition is Carmen Sotos Serrano, Los pintores de la expedición de Alejandro Malaspina, Madrid, Real Academia de la Historia, 1982, 2 vols. For Malaspina's account of his visit to California, see The Malaspina Expedition, I789-I794. Journal of the Voyage by Alejandro Malaspina. Volume II: Panama to the Philippines, Andrew David et al. (eds.), London, The Hakluyt Society, 2003, Book Seven, chapters 2 and 3, pp. 205-2I 2. Malaspina's account was not published in his lifetime, although it is reasonable to assume that he planned to do so. See Malaspina, Volume I: Cadiz to Panama, pp. XxvII-XXvII and Xxx. For a succinct description of the voyage and its context, see Donald C. Cutter's "Introduction" in Volume I: Cadiz to Panama, pp. XxIX-Lxxvir. See also Donald C. Cutter and Lawton Kennedy, Malaspina in California, San Francisco, John Howell Books, 1960. In Cutter's "Introduction" to Malaspina, vol. I, p. XVI, he reports that Cardero was "originally a criado or servant" on the voyage who replaced one of the two artists originally chosen for the expedition; Cardero was one of several artists who were part of the original expedition or who joined it en route at various ports of call. See also p. LX-LXI for a fuller discussion of the artistic enterprises of Malaspina's voyage; it appears that of the many drawings made by Cardero and other artists, some were sent back to Spain for reproduction in the planned publication of Malaspina's expedition.

4. See George Vancouver, Voyage of Discovery to the North Pacific Ocean and Round the World, London, G.G., J. Robinson and J. Edwards, I798, 3 vols.

5. For a description of the voyage see Otto von Kotzebue, Entdeckungsreise in die Südsee und nach der Beringsstrasse zur Entdeckung einer nordöstlichen Durchfahrt, unternommen in den Jahren I8I5-I8 aufKosten Sr. Erlaucht des Herrn Reichskanzlers Grafen Rumanzoff auf dem Schiffe "Rurik", Weimar, I82I, August C. Mahr (trans.) as The Visit of the "Rurik" to San Francisco in I8I6, Stanford University Press, I932. Choris published his drawings separately in Louis Choris, Voyage pittoresque autour du Monde, Paris, Imprimerie de Firmin Didot, I822.

6. Frederick William Beechey, Narrative of a Voyage to the Pacific and Beering's Strait, to cooperate with the Polar Expeditions, London, Henry Colburn and Richard Bentley, I831.

7. I am deeply grateful to Peter Hiller of Carmel, California, a Mora scholar who has organized a number of exhibitions on the artist and who has had extensive access to Mora's work and diaries. His careful reading of this article has been indispensable, though any possible errors or omissions are my own. 
tevideo, Uruguay, Mora was the second son of sculptor Domingo Mora. ${ }^{8}$ After the family emigrated to New England, both sons studied art with their father and then attended the Cowles Art School in Boston. Mora continued his studies at the Art Students League in New York, working privately as well with renowned American painter and teacher, William Merritt Chase. His first employment with The Boston Traveler and Boston Herald newspapers was short-lived, however, when in I 894 at the age of eighteen Mora headed west to work as a cowboy in Texas. A native Spanish speaker, he also traveled in northern Mexico, visiting Indian villages and meeting the famed artist of the American West, Frederic Remington, who encouraged Mora to continue his studies. In I 898 Mora was hired as a staff artist for The Boston Herald, and he soon received commissions to illustrate a number of popular classics, including The Animals of Aesop and Reynard the Fox.?

In 1903 Mora made his first trip to the former Alta California, traveling by train to San José to visit his parents who had since moved there. And, like so many visitors to the still young state, he was struck by the chain of Franciscan missions that stretched from San Diego in the south to San Francisco in the north. ${ }^{10}$ Founded by the legendary Junípero Serra and his followers, these missions were striking visual reminders of Spain's presence in California and were increasingly employed in various ways to construct the state's often romanticized early history. ${ }^{\text {II }}$ Mora was working as a cowhand at the Donahue

8. The primary sources on Mora are the exhibition catalogues, Jo Mora: Artist and Writer, Monterey, Monterey Museum of Art, 1998; and Tyrone Stewart, Frederick Dockstader, and Barton Wright, The Year of the Hopi: Paintings and Photographs by Joseph Mora, New York, Rizzoli, I979.

9. The biographical details recounted here are taken from Betty Hoag McGlynn's “Jo Mora: Spokesman for The Old West", in Jo Mora: Artist and Writer, pp. 2-Io. Mora subsequently published two books about his western experiences, Trail Dust and Saddle Leather, New York, Charles Scribner \& Sons, 1946 and Californios, Garden City, Doubleday \& Co., Inc., I949.

Io. Artistic production of images of California's missions proliferated at the end of the nineteenth century and the beginning of the twentieth, perhaps the most important early example being Carelton Watkins's series of photographs on the missions from the late I870s. Paintings of the missions also grew in number significantly from the $188 \mathrm{os}$ on; see the exhibition catalogue by Jean Stern, Romance of the Bells: The California Missions in Art, Irvine, California, The Irvine Museum, I995. There is no evidence Mora was familiar with these earlier images.

I I. The bibliography on Alta California's missions is extensive, beginning with accounts by the Franciscans who founded them. Given Mora's relationship with mission fond and preservationist Charles Fletcher Lummis, he could easily have been familiar with some of this literature. By the time Mora arrived in California in 1903 , there was a virtual industry of books and articles featuring 
Ranch outside Solvang when he discovered nearby Mission Santa Inés, which inspired him to embark on a journey to see other California missions. As he later recalled, "I had ridden down over the border from San Diego to Velicata in Baja California, from whence Portola and Serra had entered the unknown land in their march North in I 769. There I turned back and started my own jaunt to take in all the Franciscan Missions and Visitas on the old Camino Real, right up to San Francisco and Solano in Sonoma. I endeavored to follow, in the minutest detail, the trail of those early Dons." His route, he admitted, was governed by another discovery. "My guide for this was that priceless bit of Americana, Crespi's Diary. Mine was an old typewritten copy in Spanish, given to me by my friend the late Charles F. Lummis." Mora, it seems, was eager to make his journey as authentic as possible. "I identified most of his campsites, so concise and clear are his descriptions. Throughout this diary, the one objective was to find Vizcaino's glorious harbor of Monterey; and, naturally my own thoughts were turned along the same lie, and looking forward to my first squint of the Carmel Mission, which was the early headquarters of that Mission chain, and where Serra had died and was buried." ${ }^{2}$

Mora's trip began during the summer of 1903 when he rode his horse from Santa Inés over the San Marcos Pass to Santa Barbara, with sketchbook and

the missions, including Edward Vischer, Old Missions, California, San Francisco, Bancroft Co., I893; George Wharton James, Old Missions and Mission Indians of California, Los Angeles, B.R. Baumgardt \& Co., I895; Zephyrin Engelhardt, The Franciscans in California, Harbor Springs, Michigan, The Holy Childhood Indian School, I897; Mission Memories: The Franciscan Missions of California, with photographs by A.C. Vroman, Los Angeles, Kingsley-Barnes \& Neuner Co., I898; Edward Deakin, The Twenty-One Missions of California and the Old Southwest, Berkeley, Murdock press, I900; Mrs. Armitage S.C. Forbes, California Missions and Landmarks And How to Get There: A Practical Guide, Los Angeles, Issued by Mrs. Armitage S.C. Forbes, 1903; and Helen Hunt Jackson, Glimpses of California and the Missions, Boston, Little, Brown, and Company, 1903: All of these books were illustrated with halftone reproductions, in Vroman's case with his own significant photographs; and in the case of Vischer and Deakin with their paintings of the missions. Jackson, of course, was the renowned advocate of Indian rights and author of the enormously popular I884 novel, Ramona: A Story, which she intended to stir public opinion in aid of California's mission Indians. Glimpses of California and the Missions was a reprint of articles she wrote in 1883 for The Century Magazine, among them a two-part series, "Father Juniper and His Works", vol. XXVI, May-June I883, pp. 3-I8 and I99-2I4. Again, there is no evidence that Mora was familiar with this literature, though the popularization of California's mission heritage at this time would have been difficult to miss.

I 2. From a 1942 letter by Jo Mora describing his map of Carmel by the Sea. My thanks to Peter Hiller for this reference. 
camera in hand. In Santa Barbara he boarded a steamer, with his horse, to San Diego, from which he went from mission to mission as far north as San Juan Bautista. During the course of his trip, he produced a number of drawings, watercolors, and photographs of the missions on this trip. These include scenes of San Juan Capistrano, ${ }^{\text {I3 }}$ San Luis Rey, Santa Inés, San Diego, San Miguel, and San Antonio de Padua, ${ }^{\mathrm{I}}$ and San Carlos Borromeo in Carmel. ${ }^{\mathrm{I}}{ }^{5}$ These works are included in two different sketchbooks containing twenty-four watercolors and drawings, and are mentioned also in his diary entries, often detailed descriptions of these sites at the very time he made his various pictures. ${ }^{16}$

Mora's interest in the missions also extended to those in Baja California. At some point after 1903 he did views of Nuestra Señora de Loreto Conchó in Baja California, founded in 1697 by the Milanese Jesuit Juan María Salvatierra. ${ }^{17}$ Depictions of the missions of northern Mexico are rare, especially in comparison with the abundant images of the missions located in the present day American Southwest. The same impulses of exploration and adventure that brought both amateur and professional artists there only occasionally led them into what is now northern Mexico. French diplomat Eugène Duflot de Mofras' I 840-I 842 assignment to assess the political, economic, and military situation in Mexico, for example, took him to Alta California, Baja California, Sonora, and Sinaloa. In the journal he published of his travels, he briefly mentioned the formerly Jesuit Baja missions Santa Catalina Mártir, Santa Rosalía, San José Comondú, San Francisco Xavier, Santiago de los Coras, Todos San-

I3. Capistrano Arches, 1903 (pen and ink, I $3.9 \times 22.2 \mathrm{~cm}[5$ 1/2 $\times 83 / 4$ inches], Collection of Jo N. Mora), and San Juan Capistrano, 1903 (watercolor, $13.9 \times 22.2 \mathrm{~cm}[51 / 2 \times 83 / 4$ inches], Collection of Jo N. Mora), both reproduced in Jo Mora: Artist and Writer, p. I6.

I4. Mora's drawings of these are in a sketchbook in the collection of Jo N. Mora. My thanks to Peter Hiller for bringing these to my attention.

I 5. Altar, Carmel Mission, probably 1903 (watercolor and pencil, $28.6 \times 20.8 \mathrm{~cm}[\mathrm{II} 1 / 4 \times 8$ 1/2 inches], Collection of California Historical Society), reproduced in Jo Mora: Artist and Writer, p. 52.

I6. From the entries in Mora's diaries we know that he went as far north as San Juan Bautista, although he may well have continued northward on this trip. Thus far, only two of Mora's photographs of the missions made on this trip have come to light.

I7. Marco Díaz, Arquitectura en el desierto: misiones jesuitas en Baja California, Mexico City, Universidad Nacional Autónoma de México, 1986, pp. 92-I02. Two more recent sources are Ann and Don O'Neil, Loreto, Baja California: First Mission and Capital of Spanish California, Studio City, California, Tio Press, 200I, especially pp. 47-65, 86-95, and 99; and Edward W. Vernon, Las Misiones Antiguas: The Spanish Missions of Baja California, I683-I855, Santa Barbara, Viejo Press, 2002, pp. 9-18. 
tos, San Luis Gonzaga, Santo Tomás, San Miguel, San Vicente, San Francisco de Borja, San Ignacio, Nuestra Señora de Guadalupe, and Jesús María, none of which were illustrated. ${ }^{8}$ In I 850 - I 853 , John Russell Bartlett went to northern Mexico as leader of the first survey to determine the new boundary between the United States and Mexico following the Treaty of Guadalupe Hidalgo. In his I 854 report he mentioned churches in San Pedro, Santa Cruz, San Ignacio, Magdalena, Cocóspera, Imuris, Ures, and Loreto, though again none were illustrated. ${ }^{19}$ What may be the first image in American art of a northern Mexican mission shows Cocóspera, in J. Ross Browne's I 869 account of his I 864 travels in Arizona and Sonora which included trips to Imuris, Magdalena, and Santa Cruz. ${ }^{20}$ Browne also went to Baja California, visiting churches at San Antonio and Todos Santos which he wrote about and illustrated in his I 868 article for the popular periodical, Harper's New Monthly Magazine. ${ }^{2 \mathrm{I}}$

Mora's works, then, are among the very few from either the nineteenth or early twentieth century that show any of northern Mexico's numerous Franciscan and Jesuit missions. ${ }^{22}$ Because of the deterioration that missions

I 8. Eugène Duflot de Mofras' books include, Fragments d'un voyage en Californie, Paris, I843, and his better known; Exploration de l'Oregon et des Californies, 2 vols., Paris, Firmin Didot Frères, I844; and L'Oregon, le Mexique et les Etats-Unis, 2 vols., Paris, I846.

19. John Russell Bartlett, Personal Narrative of Explorations and Incidents in Texas, New Mexico, California, Sonora, and Chihuahua, Connected with the United States and Mexican Boundary Commission, during the years I 850, 5I, 52, and 53, 2 vols., New York and London, D. Appleton \& Co., I854, vol. I, pp. 408-440 for his descriptions of these churches.

20. J. Ross Browne, Adventures in the Apache Country: A Tour through Arizona and Sonora, with Notes on the Silver Regions of Nevada, New York, Harper \& Brothers, I869, p. I80.

2 I. J. Ross Browne, "Explorations in Lower California (First Paper)", "Explorations in Lower California (Second Paper)", and "Explorations in Lower California (Third Paper), in Harper's New Monthly Magazine, vol. XXXVII, no. CCXXI (October I868), pp. 577-592; no. CCXXII (November 1868), pp. 740-752; and no. CCXXIII, pp. 9-23, respectively. San Antonio is illustrated on page 743 and Todos Santos on 749 of the November article.

22. The Franciscan and Jesuit missions in what is now the United States were, of course, part of the same combined religious, political, and military enterprise. Those in the United States number more than one hundred, the actual number depending on whether the count takes in all those known to have been founded from documentary sources, many of which were shortlived (and even if any substantial buildings were erected they may have long since disappeared). Counting only extant structures the number falls to approximately fifty in California, Arizona, New Mexico, and Texas. By contrast, there were and are many more in northern Mexico, where hundreds of missions were founded with churches and other structures erected, some one hundred and fifty in the state of Chihuahua alone; see, for example, Clara Bargellini (coord.), Misiones para Chihuahua, Mexico City, México Desconocido, 2004. 
on both sides of the current border suffered as a result of Mexico's secularization decrees of 1834 , they are particularly important in documenting Loreto's state of preservation. ${ }^{23}$ French diplomat De Mofras visited Loreto in I 840 and noted that the church was already deteriorating. "The settlement of Loreto has approximately 200 inhabitants", he reported.

At one time this mission was the capital of Lower California, but it has fallen into decay and its prestige transferred to the Real de San Antonio. The presidio, mission, and church are now slowly crumbling away, although the buildings were constructed in a substantial manner by the Jesuit Fathers, being designed to afford shelter, in case of attack, to the colonists [...] The church still contains a large number of paintings, silver cases, and some valuable jewels belonging to the Virgin. Although these objects are placed in the altar and in the sacristy, the doors are never closed, for no one would dare commit a sacrilegious theft. ${ }^{24}$

Unfortunately, the circumstances surrounding Mora's making of his two watercolors are not known. According to the artist's later recollection, after arriving in San Diego in 1903 he rode to Velicatá, where he presumably visited Mission San Fernando Rey de España de Velicatá, located some 300 miles due south of the U.S.-Mexico border and no doubt further by whatever route he took on horseback. ${ }^{25}$ This would have left him nearly $965.4 \mathrm{~km}$ (60o miles)

23. The much dilapidated condition of these missions was noted consistently by visitors, including Bartlett and Browne, as it was by mid-nineteenth-century travelers to the missions of Alta California. Secularization, essentially removing control of the missions from the orders and turning them over to secular clergy, quickly resulted in abandonment of the missions, and at the very least deprived many of them of their funds and frequently their priests. Within as little as ten to twenty years after secularization, in fact, reports abound of Alta California missions in near total ruin, their roofs collapsed, walls crumbling, and their Indian populations dispersed. Bartlett's and Browne's offer similarly graphic comments about missions in northern Mexico. For a brief discussion and photographs of the church at Loreto from I905 to around 1945, see O’Neil, pp. 199-205.

24. Duflot de Mofras, Travels on the Pacific Coast: A Report from California, Oregon, and Alaska in I 84I, Oregon, The Narrative Press, 2004, pp. I42-I 43. This translation is a reproduction of Marguerite Eyer Wilbur's translation of Duflot de Mofras' 1844, Exploration, published as Duflot de Mofras' Travels on the Pacific Coast, Santa Ana, The Fine Arts Press, 1937, with Foreword by Dr. Frederick Webb Hodge.

25. For a description of that mission, see Edward W. Vernon, Las Misiones Antiguas. The Spanish Missions of Baja California, Santa Barbara, Viejo Press, 2002, pp. I7I-I80. 
northwest of Loreto, located on the Sea of Cortés, and given both the distance and the other Jesuit missions he likely would have seen along his route, it seems highly unlikely he would not have mentioned the trip or that he would not have made additional works depicting these equally picturesque Jesuit missions. Even from his known stop at Velicatá, he could have visited El Rosario, San Pedro Mártir, Santo Domingo, San Vincente, Santo Tomás, Santa Catalina, San Miguel, Guadalupe, and El Descanso, all located between Velicatá and the U.S. border and of which there are no known works by Mora. In any event, there is no evidence that Mora made his watercolors of Loreto during his 1903 journey, nor has any other evidence yet come to light to suggest when he did. ${ }^{26}$

Regardless of when they were done, the watercolors offer important information about the mission at Loreto. ${ }^{27}$ His view of the exterior, for example (fig. I), shows both the complex as a whole in its lower portion and "Neophyte Huts" and the "Typical Type of House at Loreto" in the upper. Comparing the former with the current appearance of the church reveals that the tower on the façade was topped by a single arched window story rather than the twostory version that is there today. In addition the sculpture niche and arched cornice, now seen above the choir window was originally a simpler rectilinear

26. Each of the watercolors carries the stamp "Mindenberg Productions", which, it has been suggested anecdotally, refers to a movie company that may have commissioned Mora to make them, perhaps as set designs. According to Peter Hiller, who gave me this information in a telephone conversation on February 17, 2006, it is known that Mora was occasionally commissioned to make such drawings, and Mora's journals may yet reveal information about the circumstances surrounding the Loreto watercolors. This author's extensive research on American movies in which missions have been featured (presented in an unpublished paper, "Missions at the Movies", at the October 2006 Southwest Art History Conference in Taos, New Mexico), however, has not identified any such movies that were actually produced. Moreover, missions in those movies that were produced are limited almost exclusively to those in the American Southwest. In addition, no information has yet been discovered on "Mindenberg Productions."

27. The question should be raised whether Mora made these watercolors based on a photograph or other published illustration of the mission. While it cannot be determined whether or not he did, it is true that very few of Mexico's missions enjoyed the popularity of those in the United States, where there is a long pictorial and narrative tradition in which they figure. The missions of northern Mexico, in particular, are located in regions that were rarely, if ever, visited by either Mexican or American artists of even the most modest reputations. It is therefore difficult to imagine what source Mora may have depended on if he were, in fact, making his watercolors in this fashion. 


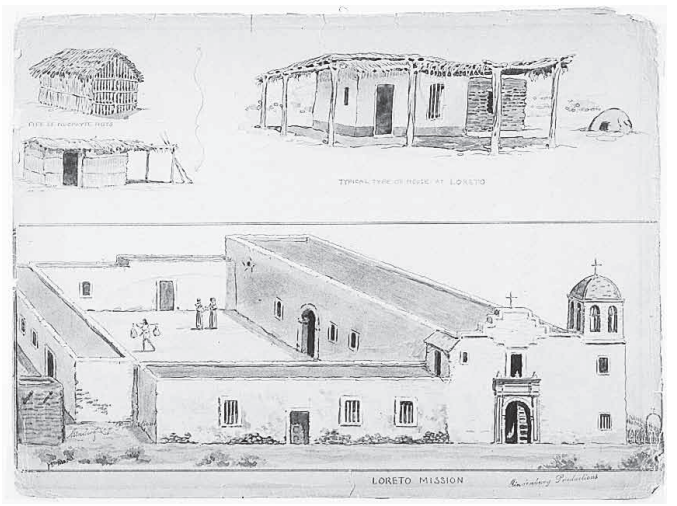

I. Jo Mora (1876-1947), Loreto Mission, watercolor and graphite on paper, $29 \times 38 \mathrm{~cm}$. Reproduced with permission of the California Historical Society.

stepped structure. ${ }^{28}$ And as was typically the case in images of the missions in both the southwestern United States and northern Mexico, structures by or for the native inhabitants to whom the missionaries were initially dispatched in these distant and often remote regions were also depicted. Mora identified the modest structures in his title, in fact, as the dwellings of "neophytes", a term used to describe Indians who had been baptized and who were being instructed by the missionaries in the tenets of the Catholic faith.

Mora's watercolor of the interior is equally important (fig. 2). It shows the mission's main altar. A balustrade separates the presbytery from the rest of the church. Beyond it, one can see the altar with its tabernacle and crucifix. Behind the altar, on a platform integrated into the lower wall, is a painted and sculpted altarpiece, flanked by large candelabra. To the right, two large paintings adorn the walls, and the church's carved beams are readily visible above. Mora's well-preserved watercolor gives a sense of the main altar's vibrant blue and red colors, though whether these colors are original cannot be stated with

28. A lithograph of the mission published by the Mexico City weekly La Ilustración Mexicana in the I850s, entitled Vista por lo Oeste de la Misión de Loreto fundada en 1742 Baja California shows the same tower. The lithograph, one of the very few produced in Mexico of any of the country's northern missions, is reproduced in José N. Iturriaga, Litografía y grabado en el México del XIX, Mexico City, Telmex, 1994, t. II, p. Ior. Photographs of both the interior and exterior of the church as it appears today can be found in Vernon, Las Misiones Antiguas, pp. IO-I5. 


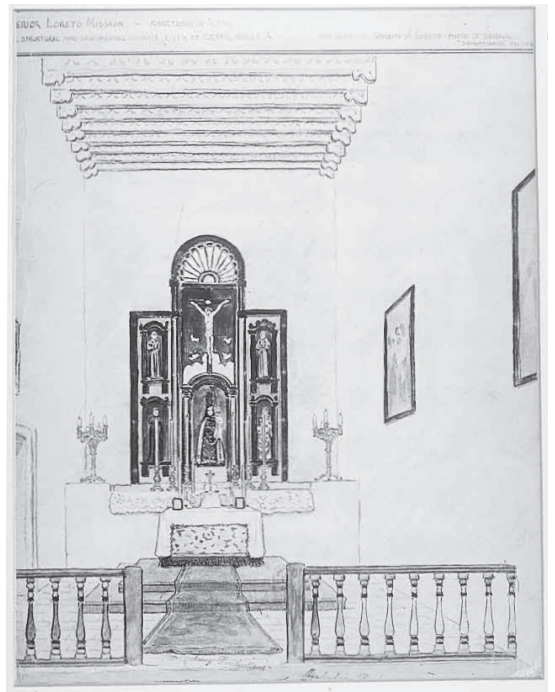

2. Jo Mora (I 876-1947), Interior, Loreto Mission, watercolor and graphite on paper, $3 \times 27 \mathrm{~cm}$. Reproduced with permission of the California Historical Society.

certainty, as it would not be uncommon for the altar to have been repainted more than once since its installation in $1744 \cdot{ }^{29}$ Moreover, despite its small size, it reveals important details about the altar's structure and imagery as they appeared when Mora was there and which changed dramatically in the first half of the twentieth century. ${ }^{30}$ As seen in Mora's watercolor, the central section of the altar had a large crucifix at the top, which would be one of the two polychrome wood sculptures found today in the mission museum. ${ }^{31}$ Below the crucifix is the easily recognizable image of the Virgin of Loreto, the church's namesake. Today there are two images of Loreto in the church, a much restored eighteenth-century sculpture in the main altarpiece which is probably the one depicted by Mora, and another in the chapel on the epistle side of the church which may well be the original Virgin of Loreto brought by Salvatierra. ${ }^{32}$ In niches to the right and left of this central section are standing

29. Díaz, Arquitectura en el desierto, p. 95.

30. See Vernon, Las Misiones Antiguas, p. I5, for a photograph of the altar as seen today.

3 I. Bárbara Meyer de Stinglhamber, Arte sacro en Baja California sur, siglos XVII-XIX, Mexico City, Instituto Nacional de Antropología e Historia, 200I, pp. 60, 6I.

32. Ibidem, pp. 67-68. My thanks to Clara Bargellini for her assistance with comparisons of Mora's depiction of the central altar and various still extant paintings and sculptures. 
saints which in Mora's watercolor are unfortunately too small and lacking sufficient detail to identify.

Although the extent of Mora's interest in the missions of Baja is still to be fully revealed, other works of his make clear how profoundly he was affected by his exposure to California's mission history. In I 924 Mora completed a commission for his monumental Serra Cenotaph. This life size tomb sculpture of bronze and California travertine marble in the Franciscan's home mission, San Carlos Borromeo, shows the recumbent Serra with his fellow missionaries Crespi, López, and Lasuén kneeling reverently at his side. ${ }^{33}$ Bronze and marble reliefs immediately below tell the story of the friar's accomplishments in Alta California. They also include carvings of Spain's coat of arms surrounded by the knotted cord of the Franciscans, a portrait of Carlos III, and another of Pope Pius V which together symbolize the religious and political interconnections that supported Serra's and his fellow Franciscans' efforts to convert the Indians of Alta California. In the richness of its imagery and the sensitivity with which its many scenes were rendered, Mora's tomb is perhaps the fullest expression in any art work of the nineteenth or twentieth century of Serra's important role in California's history. ${ }^{34}$ Mora, consequently, was one of the very few American artists to explore through his work in both Alta and Baja California the fuller story of the Franciscan and Jesuit mission enterprises in what was once northern New Spain. \$

33. The tomb is illustrated in McGlynn, "Jo Mora: Spokesman", p. 23.

34. In 1926, Mora completed a Serra shrine consisting of a wood sculpture of the Franciscan surrounded and covered by a tile-roofed structure, commissioned as part of a new real estate development in Carmel by Del Monte Properties; see McGlynn, "Jo Mora: Spokesman”, pp. 26-27. 